\title{
MODIFICATION OF THE STRUCTURE BASED ON CASE STUDY ON LARGE SCALE POULTRY LAYER UNIT FOR 8500 BIRDS
}

\author{
Mohammed Thousiff S \\ Assistant Professor, Department of Agriculture Engineering \\ Sri Shakthi Institute of Engineering and Technology, \\ Coimbatore, Tamilnadu, India
}

\begin{abstract}
Generally, Chicken welfare has been characterized by the nonappearance of negative states, for example, infection, appetite and thirst. In any case, a move in chicken welfare has prompted the arrangement that great creature government assistance can't be accomplished without the experience of positive states. Unequivocally, the lodging climate impactly affects creature government assistance. This survey sums up the specifications and components needed in the confine framework poultry cultivating in layer unit for 8500 hens that is considered as a huge scope poultry arrangement. Also,the assessment for setting up this poultry confine ranch is finished with the evaluation of materials embraced, sorts of bracket to be utilized and other basic cum dividing subtleties moreover. The design of the structure is done using STAADPRO thereby estimating the minimal amount of cost required for rearing 8500 birds.
\end{abstract}

Keywords - Poultry, Layer unit, cage system, spacing cum structural details, Estimation.

\section{INTRODUCTION}

Chickens are social creatures and live in a little gathering in nature. They invest a great deal of energy scratching and rummaging for food on the ground and perform heritable practices, for example, dustbathing and prelaying settling. In the business poultry industry, layers are principally housed in battery confines (likewise called customary pens) Hossary M.A. et al. Around the world, battery confine frameworks evoke a lot of discussion relating to the general impact of the training on winged creature prosperity. The gave benefits are of keeping up a little gathering size, with a low degree of social pressure, bringing about low hostility and savagery, high egg creation, and expanded cleanliness, which may in fact support improved prosperity in confined fowls Sing V.P et al. Furthermore, financially, battery confines are exceptionally productive on the grounds that huge quantities of flying creatures can be housed in severe restriction with profoundly motorized feed and water frameworks, with fertilizer and eggs gathered consequently. For this situation,

\author{
Anila Dani D.A. \\ Asst Professor,Dept of Civil Eng., \\ RVS Technical Campus, Coimbatore
}

battery confines advantage both the feathered creatures and makers.

Nonetheless, there is impressive morphological, physiological, and conduct proof exhibiting pressure responses in chickens raised in the battery confine frameworks in light of the fact that there are no critical changes in feathered creatures' natural and social qualities through specifically rearing for egg profitability Tufail $\mathbf{M}$ et al . Homegrown feathered creatures may at present like to play out certain common practices; in any case, inside the battery confines, the fowls' conduct collection is limited and bone quality is diminished by the congestion and fruitless climate Słupczyńsk M et al.Because of those impacts, there is developing weight from creature prosperity and buyer bunches upholding the restricting of battery confine frameworks in the poultrybusiness.

Presently, specialists are inspecting different lodging frameworks, for example, profound littered lodging, aviaries, floor pens, move away pens, unfenced, and outfitted confines and evaluating the impact on the government assistance of flying creatures housed in those conditions. Among the other options, outfitted (additionally called advanced) confine frameworks may offer a more appropriate lodging framework for both improving prosperity for winged animals and keeping up profile for makers Maharjan P et al. Outfitted enclosures endeavor to give advancement to feathered creatures while as yet exploiting the advantages of a little gathering size. Past examinations have indicated that winged creatures housed in the outfitted confines likewise improve prosperity by decreasing trepidation, hostility, and quill pecking and expanding bone mineral thickness Although outfitted enclosure frameworks appear to be a potential path for improving fledgling prosperity, its persuasions have been demonstrated to be strain-, age-, and office subordinate. Prior to suggesting its far and wide use inside the egg business, a full assessment should be done to contrast it and regular broad lodging framework.

Merino L et al., A profound litter sheet material can develop to profundities of 1-2 meters. The typical technique for developed floor litter is to begin with around 4 creeps of 


\section{International Journal of Engineering Applied Sciences and Technology, 2020 \\ Vol. 5, Issue 6, ISSN No. 2455-2143, Pages 257-260 \\ Published Online October 2020 in IJEAST (http://www.ijeast.com)}

fine litter material with augmentations of 1 to 2 inches later varying without expulsion of the old. A profundity of 6 to 12 inches is kept up by fractional expulsions every once in a while so their excreta will be cleaned at proper time. The goal of this examination is to decide the powerful determination of sorts of enclosure frameworks, floor space required and its absolute assessed cost.

\section{PROPOSED ALGORITHM}

\section{A. Materials and Methods-}

Floor Space Required(Cage System)

- $\quad$ Chick -0.3 sq.ft

- $\quad$ Grower -0.5 sq.ft

- $\quad$ Layer -1 sq.ft

Bottom of the cage is provided with the slope of 1.5 " per running feet (ie.12'), so as to make the eggs to roll over and collect on the egg tray.

Specification of a Cage

$\mathrm{L}=16$ inches $=1.33 \mathrm{ft}$

$\mathrm{B}=18$ inches $=1.5 \mathrm{ft}$

Therefore, Floor area of each cage $=1.33 \times 1.5=1.995$ sq. $\mathrm{ft}$ (App 2sq.ft) $\mathrm{H}=18$ inches= $1.5 \mathrm{ft}$.

Therefore, in a single standard cage we can accommodate two birds in layer unit.

Based on the arrangement of cages, the cage systems is classified into following types-Single deck cage, Double-deck Cage, Triple - deck Cage, Four -deck Cage. Among this, the double deck cages are widely used because of ease in operation and maintenance. All poultry structure using cage system will be elevated to a height of $6 \mathrm{ft}$ from ground level(One man can walk under this and can collect the manures easily).Such type of elevated structure is called as California Housing.

\section{B. Floor space and configuration -}

Total Height of the structure

Total Height- $6 \mathrm{ft}($ elevated Column)+ $8 \mathrm{ft}$ (upto bottom chord of the truss ) $+6 \mathrm{ft}$ (from bottom chord to ridge point of the truss $)=20 \mathrm{ft}$.Eave Height $=14 \mathrm{ft}$. Ridge Height $=20 \mathrm{ft}$

Ridge Ventilation is adopted mostly, since it is economical than mechanical ventilation in poultry farms.For an economical design, the width of the structure is maintained between $30 \mathrm{ft}$ to $35 \mathrm{ft}$ and the length is changed based on number of birds to be reared and the plot size.

Calculation of Structural floor space required for 8500 birds-
Floor Space required for one bird(in layer cage) 1sq.ft.Hence, for 8500 birds, the floor space required $=8500$ sq.ft.

\section{Floor space required for footpath}

Number of rows (bird cage) $=3$, separated by a footpath of width $3.5 \mathrm{ft}$.

Width required for one footpath $=3.5 \mathrm{ft}$.

Length of one footpath $=500 \mathrm{ft}($ length of the structure).

Number of footpaths(along length-wise)=4 (for three row cages)(Because of egg collection and feed supply on either sides).Total footpath area required(along length-wise) $=3.5 \mathrm{x}$ $500 \times 4=7000$ sq.ft - (i) Footpath perpendicular to door$(6 \times 6)=36 \mathrm{ft}$. Number of cage rows $=3$.

Total footpath area required(along width-wise) $=36 \times 3$ $=108$ sq.ft. Number of divisions(along width-wise) -3 (one from center and the two extreme ends)

Therefore, 108 x $3=324$ sq.ft

Therefore, the total footpath area required $=7000+324=$ 7324 sq.ft. For Stairs and other miscellaneous work like water tub, sweeping equipment etc, additional 100sq. $\mathrm{ft}$ is provided approximately.

Therefore total floor area required for 8500 birds = $(8500+7324+100)$

$=15924$ sq. $\mathrm{ft}$

For 8500 birds(out of which $10 \%$ are male), the structure floor space required is $32 \mathrm{ft} \times 500 \mathrm{ft}$ (in double deck cage system)-including water supply system.

Fogger is used to maintain the humidity of the poultry farm thereby controlling the temperature. Distance between two foggers is $2.66 \mathrm{ft}$. Drippers(or Nipple Watering System) can be placed at a spacing between $1 \mathrm{ft}$ to $1.5 \mathrm{ft}$,so as to provide required quantity of water supply. In cage system, Stainless Steel Corrugated roofing sheet, asbestos roofings or concrete roofings are used, whereas in conventional deep litter system thatched roofing can be adopted. Roof Slope depends on the width of the building. 


\section{International Journal of Engineering Applied Sciences and Technology, 2020 \\ Vol. 5, Issue 6, ISSN No. 2455-2143, Pages 257-260 \\ Published Online October 2020 in IJEAST (http://www.ijeast.com)}

\section{EXPERIMENT AND RESULT}

The detailed estimate for cage system for 8500 birds are as follows:

Table -1 Estimation

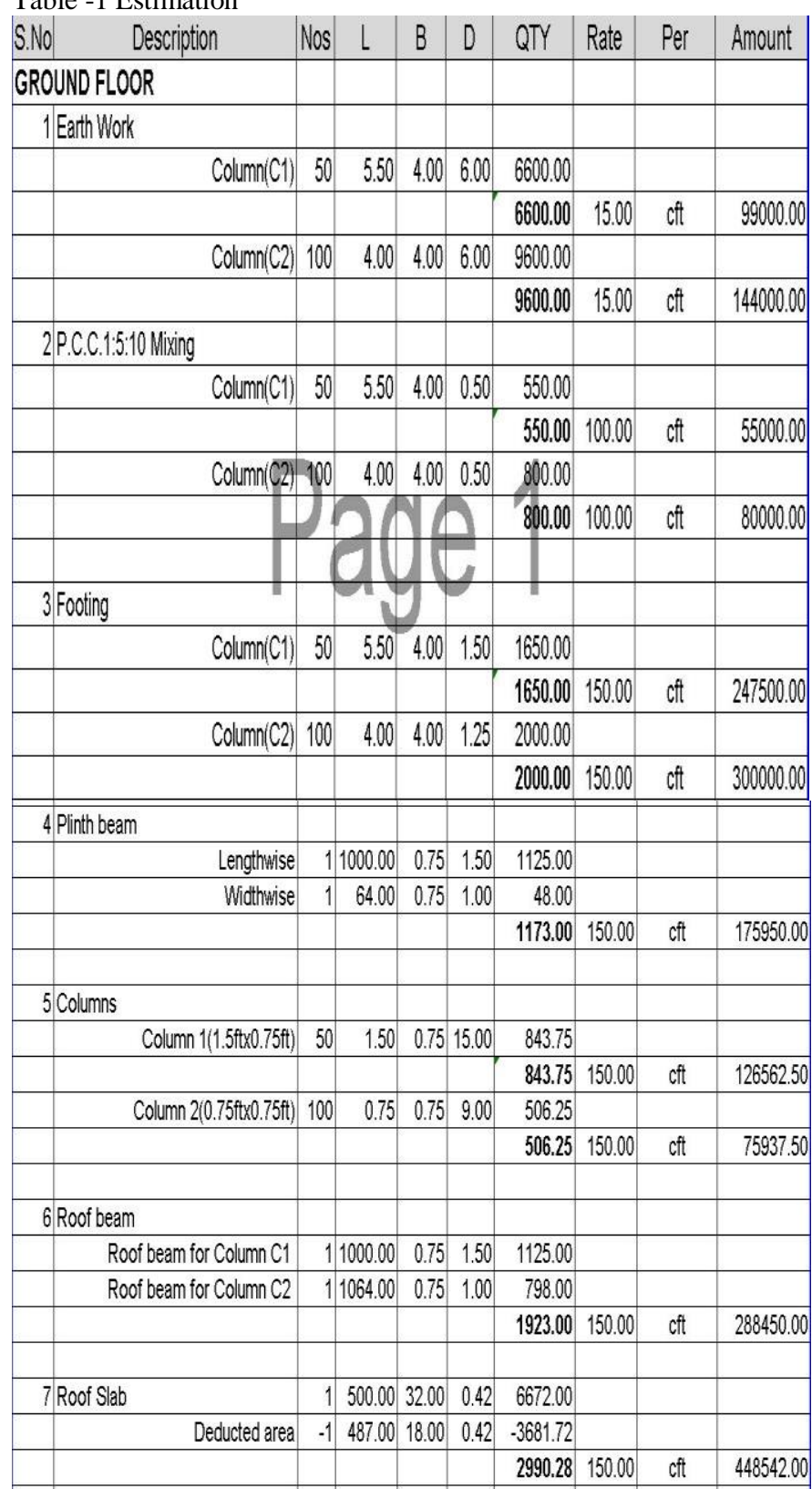

8.Truss (ISLB125)-Weight per metre $=11.9 \mathrm{~kg}$. Material length needed of single truss $=36.82 \mathrm{~m}$. Total number of trusses $=25$ Total length needed $=920.5 \mathrm{~m}$

$$
\text { weight }=11.9 \times 920.5=10954 \mathrm{~kg} \text {. }
$$

Cost of Stainless steel hot rolled roof truss $=\mathrm{Rs} .85 / \mathrm{kg}$. Therefore, Total cost for truss =Rs.931090/-Purlins (ISMC 125)-Weight per metre $=12.7 \mathrm{~kg}$, Material length needed of single purlin $=500 \mathrm{ft}=152.44 \mathrm{~m}$, Total Number of purlins $=7$, Total weight $=1067 \mathrm{Kg}$.

Cost of mild steel ISMC 125 purlin $=$ Rs. $35 / \mathrm{kg}$.

Therefore total cost for purlins =Rs.37345/-

Stainless steel corrugated roofing sheet-Rs.320/Sq.m

Total area of roofing sheet $=1766$ Sq.m

Total Cost for roofing sheet $=$ Rs.565120/-

Sintex Tank-750litres, Quantities required -2

Cost of each one=Rs.5900/-

Total cost for water tank - Rs.11800/-

Plastic pipes(1/2 inch diameter)

Total length required $=2500 \mathrm{~m}(\mathrm{app})$

Total cost for pipes $=$ Rs .250000

Total cost for nipple drinker=Rs.46000

Curtains-Polyethylene laminated sheets

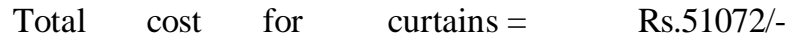

Total cost for poultry fogger $=$ Rs.38700/-

Table 1 show the estimation for poultry setup for 8500 birds including all necessary amenities. The total estimated cost is Rs.39,72,068/-

\section{CONCLUSION}

Each method of poultry rearing will exhibit different pros and cons with respect to space requirement, growth of the bird, egg laying capacity, lifespan of the bird. The space required for poultry in extensive method of rearing is twice as that of intensive method of farming(Cage system). In cage system, double deck floor cage system is highly adopted because of its operation feasibility. The cost required for rearing 8500 birds is Rs.39,72,068/- as per Indian price. The selection of site, house orientation, optimum dimensions of the structure based on number of birds reared are estimated.

\section{REFERENCE}

1. Khan.A.G(2008), "Indigenous breeds, crossbreds and synthetic hybrids with modified genetic and economic profiles for rural family and small scale poultry farming in India," World's Poultry Science Journal, vol. 64, no. 3, pp. 405-415. 


\section{International Journal of Engineering Applied Sciences and Technology, 2020 Vol. 5, Issue 6, ISSN No. 2455-2143, Pages 257-260 \\ Published Online October 2020 in IJEAST (http://www.ijeast.com)}

2. Hossary M.A and Galal S, (1995)"Improvement and adaptation of the Fayoumi chicken," Animal Genetic Resources Information, vol. 14, pp. 33-42.

3. Magothe T.M, Okeno T.O, Muhuyi W.B, and Kahi A.K(2012), "Indigenous chicken production in Kenya: II. Prospects for research and development," World's Poultry Science Journal, vol. 68, no. 1, pp. 133-144.

4. Abedullah., Maqbool A and Buhsh R. (2007). Issues and economics of poultry production. A case study of Faisalabad, Pakistan. Vet. J. 27(1): 25-28.

5. Bano R, Shah H, Sharif M and Akhtar W (2011). 'Profitability index and capital turn over in open house broiler farming: a case study of district Rawalpindi’'. J. Agric. Res. 24:1-4.

6. Sing V.P,Sharma V.K.,Sidhu M.S., and Kingra H S(2010). Poultry farming in Punjab: An economic evaluation and export competitiveness. Agric. Econom. Res. Rev. Vol. 23.

7. Udoh, E.J. and Etim N.A (2007). Application of stochastic production frontier in the estimation of technical efficiency of cassava based farms in Akwa Ibom State, Nigeria. Agric. J. 2(6): 731-735.

8. Tufail M., Syed M.Z, Sohail M and Ahmad I( 2012). Economic of backyard poultry in tehail Matta District Swat. Sarhad J. Agric. 28(3).

9. Stanley V.G, Bailey J.E, Krueger W.F.(1989). Effect of iodine-treated water on the performance of broiler chickens reared under various stocking densities.(pp. 435-437)

10. Słupczyńsk M, Jamroz D, Orda J, Wiliczkiewicz A.(2014). Effect of various sources and levels of iodine, as well as the kind of diet, on the performance of young laying hens, iodine accumulation in eggs, egg characteristics, and morphotic and biochemical indices in blood.(pp. 2536-2547)

11. Boorman K.N. (1979). Regulation of protein and amino acid intake. In: Food Intake Regulation in Poultry. ( pp. 87125)

12. Maharjan P, Huff G, Zhang W, Watkins S.(2017). Effects of chlorine and hydrogen peroxide sanitation in low bacterial content water on biofilm formation model of poultry brooding house waterlines. (pp. 2145-2150)

13. Ahl A.S, Bunta B.(1997).Risk and the food safety chain: animal health, public health and the environment.(pp. 322-330) 